\title{
The Analysis Speech Acts of Donald Trump's Speech
}

\author{
Sonya Widya Febriana1, Muziatun Fajariah², \\ ${ }^{1}$ IKIP Siliwangi \\ ${ }^{2}$ IKIP Siliwangi \\ ${ }^{1}$ sonyawidyafebriana@gmail.com, ${ }^{2}$ muziatun.fajariah@yahoo.com
}

\begin{abstract}
This research is entitled the analysis speech acts of Donald Trump's speech. The study analyze the speech acts of President Donald Trump's speech. The speeches used as the data are taken from White House online on September until October 2017 in USA. Moreover, the researcher focused on speech act of illocutionary acts. In this study the research used theory from Searle. From Donald Trump's speech, the researcher found 7\% Declarative, 18\% Representative, 31\% Expressive, 29\% commissive, and 15\% Directive. The result showed that President Donald Trump's more on sentence expressive. Analysis speech act help in the interpretation of the message in the selected speech.
\end{abstract}

Keywords: Speech act, types of speech acts

\section{INTRODUCTION}

According to E. Sapir in (Kaswan \& Suprijadi, 2011) language is a purely human and non instinctive method of communicating ideas, emotions and desires. Language is one of the important part in social environment. When we propose to speak we formulate what we say to be fit the context or situation. It means that what we say is not precisely what we propose to convey, the meaning beyond the words or sentences is sometime different from the form of words. Study about meaning called pragmatics. Leech in (Jabber, Wahaab \& Jinquan, 2013) told that pragmatic is how language is used in communication. In pragmatics one of the most important phenomenon is speech act, the propositions or locutions performed depend on the speaker's intention and the context in which the propositions are uttered.

(Lyons, 1977) stated that speech act is an act performed in saying something. According to (Searle, 1976) carrying out speech acts such as making statements, giving commands, asking questions or making promises. He stated that all linguistic communication includes linguistic (speech) acts.Therefore, the speech acts theory is importance in the field of linguistics for the following reasons. Speech acts tells about about use of language in the societies.

Additionally, (Byon, 2006) said that "speech acts reflect the fundamental values and social norms of target language and demonstrate the rules of language use in a speech community". Speech act includes the linguistic functions and speeches conveyed by the speaker is to know the meaning of the language use of the language contained therein.In the speech, language is used to make things happen. The choice of language depends upon a number of factors, like social customs, traditions, culture, relationship between speakers and the kind of situation.

In this study, researchers intend to analyze the speech that is often delivered by Donald Trumps in a weekly address for American citizens. As president of the United States, the language is a consideration of special interest. Appropriate and meaningful in his speech. The transcribed greeting text has been used for analysis. 
According to (Suprijadi, Lisdawati, Fauziah, \& Supartini, 2016) actions that carried out by language are called speech acts. The utterance produced by the speakers often carry out actions such as to inform, to persuade, or to express feeling this is often called speech acts. With regard to speech acts, the following present the definition and categorization of speech acts.

Edward in (Suprijadi et al., 2016) categorized acts into two components. Utterance that represented by a sentence using grammatical structure and linguistic meaning called the locution. And some intention of the speaker in making utterance and what they expect to achieve is called an illocution. In addition, Austin in (Dylgjeri, 2017) categorize into three classes, which are: locutionary, illocutionary and perlocutionary acts. A locutionary act is an act of saying something; that is, the act of making an utterance. Illocutionary acts are the main of some theory of speech acts. The perculotionary act is the effect on the feelings, beliefes or action of the listener/hearer.

Bellow are Austin's in (Searle, 1976) five categorize of speech acts:

1. Verdictives involves in the delivering of finding, official or unofficial, upon evidence or reason as to value or facts. Example of verbs in this class are: release, hold, determine, describe, analyze, guess, assess and characterize.

2. Excercitives is the giving of decision in favor of or against a certain course of action or advocacy of it. Some example are: , command, direct, plead, request and recommend. As well as the above, Austin also lists: appoint, dismiss, nominate, refusal, announce, as well as declare, caution and give.

3. Commissives is to commit the speaker to a certain course of action. Some of the clear examples are: promise, swear, pledge, agreement, contract, and guarantee, embrace and swear.

4. Expositives are used in acts of explnaation involving expound the views, the conducting of arguments and the clarifying of usages and references. Example of these are: affirm, reject, emphasize, illustrate, answer, report, accept, admit, describe, identify, and call.

5. Behabitives includes the idea of response to other people's behavior and fortunes and of attitudes and expressions of attitudes to someone else's part conduct or imminent conduct. Example of these are: apologize, express thank, deplore, symphatize, congratulate, felicitate, welcome, appreciate, criticize, bless, curse and drink.

(Searle, 1976) classify speech acts into five main types:

1. Representatives (assertive) represent a state of affairs: assertions, statements, claims, hypothesis, descriptions, and suggestions. Representative can generally be characterized as true or false and expresses the speaker's belief.

2. Directives is expresses the speaker's desire to get the addressee to carry out an action or to do something: commands, request, challenging, invitations, entreaties, dare, ordering, defying.

3. Commissives expresses the speaker's intention or commit the speaker to some future action: promising, pledging, vows, offer, refusal, threat.

4. Expressive indicate the psychological state, attitude or the speaker's emotions, include: thanking, apologizing, congratulating, deploring, welcoming, blaming, praising, condolences, thanksgiving, greeting.

5. Declaration (declaratives) is about the state of affairs they name such as blessing, firings, resigning, baptism, arrests, dismissing, christening, naming, sentencing, marriages, declaring mistrial. 


\section{METHOD}

This research tries to reveal the speech acts that often used by Donald Trump's in his speeches. This research applies qualitative method to analyze the data. Qualitative research is applied to analyze the data in the form of the text in speeches.

\section{a. Data Collection Technique}

The technique of data collection in this research is documentary study. This research applies a documentary study because the data is in the form of document or written text. In this study, the data are taken from the official website of online Weekly Address https://www.whitehouse.gov/news/. There are 76 utterances produced by Donald Trump. The data will be collected in several steps: first, the researcher the selects President Donald Trump's speech about America in the white house. Second, the researcher analyze speech act that used by Donald Trump. And the last, the researchers classify all speech acts based on speech acts used by Donald Trump in every sentence.

\section{b. Data Classification}

After all data are collected, the data is classified into five main types of speech acts i.e. representative, directives, commissives, expressive and declarative. A data is viewed as representative when the statement express speaker's believe. The data is regarded as directive when the statement indicate request, command, suggestion, etc. The data is regarded as commissive when the statement shows the speaker promise, it can be found from the verb such as promise, pledge etc. the data is regarded as expressive when the statement shows emotions or feeling the speaker's. And the last, the data is regarded as declarative when the statement indicate that speaker declare something.

\section{RESULTS AND DISCUSSION}

\section{Results}

There are 76 utterances and all utterances are categorized on table below:

\section{The Frequency of Speech Acts Found in Donald Trump's Speeches}

\begin{tabular}{cccc}
\hline No & Illocutionary Acts & Frequency & Percentages (\%) \\
\hline 1. & Representatives & 14 & $18 \%$ \\
\hline 2. & Directives & 12 & $15 \%$ \\
\hline 3. & Commissives & 22 & $29 \%$ \\
\hline 4. & Expressive & 24 & $31 \%$ \\
\hline $\mathbf{5 .}$ & Declarative & 6 & $7 \%$ \\
\hline & TOTAL & 76 & \\
\hline
\end{tabular}

This table shows the percentage of types of speech acts used by Donald Trump.

\section{Discussion}

The result of the analysis of speech acts shows that the highest of speech acts used by Donald Trump is expressive 31\%. And the lowest speech acts is declarative with the percentage $6 \%$. 


\section{a. Expressive}

The analysis shows that Donald Trump's use many expressive utterances than the other types of speech acts. Donald Trump uses expressive in order to represent psychological state or emotion, to state what he really feels. As (Yule, 1996) argued that expressive are those kinds of speech acts that state what the speaker feels. In his speeches, Donald Trump uses some kinds of acts that belong to expressive. There are 24 utterances that belong to expressive such as condolences, sympathy, thanking, happiness, expression of disappointment, etc. "This week, the United States celebrates the 230th Anniversary of the signing of our remarkable Constitution." It is example of expressive because the statement shows emotion of happiness. The emotion can be seen by the use of verb celebrates.

\section{b. Commissive}

In this case, there are 22 utterances of commissive. Donald Trump used these kinds of speech acts because he wants to do an action in the future consists of promising, vows, commit, pledge, etc. "First, we will cut taxes on all Working American Families. People will pay a lot less money." It is example of commissive because the speaker promises to listener. It can be seen by the use of verb will. In the statement we can see that Trump promised American people pay lower taxes.

c. Representative

Representatives are also found in this analysis because Donald Trump try to represent a situation or condition which can be assumed as truth or falsity. There are 14 utterances of representative consists of stating, informing, confirm, etc. In this case, the most dominant act used by Donald Trump is informing. "The fifty-five Delegates to the Grand Convention in Philadelphia met from May to September of 1787". It is example of representative because the speaker inform the fact to the listener about the fifty-five delegates. This fact can be seen by use of verb met. It means that the fifty-five delegates hold on May to September.

\section{d. Directive}

In this case, there are 12 utterances of directive consists utterances of asking, inviting, request, etc. "So let us pledge allegiance to our flag, devote our hearts to our country, and demonstrate our love for one another-as Americans, as Patriots, and as the children of

God." It is example of directive because the speaker invite someone to do something. This invitation can be seen by the use of verb let us. In the statement above we can see that Trump tried to ask people to demonstrate, devote and pledge the nation.

\section{e. Declarative}

The last speech acts is declarative, there are 6 utterances of declarative. For example, the President declared something, "Congress ultimately decided that a star would be added to our flag's "constellation" on the Fourth of July upon the admission of each new State to the union, but that the flag would always keep its 13 stripes as a tribute to the original colonies that declared and won their Independence together." This statement is declaratives because the use of ultimately decide. The word ultimately indicates full confidents in declaring something, it also supported by the verb decided. 


\section{Donald Trump's speechees}

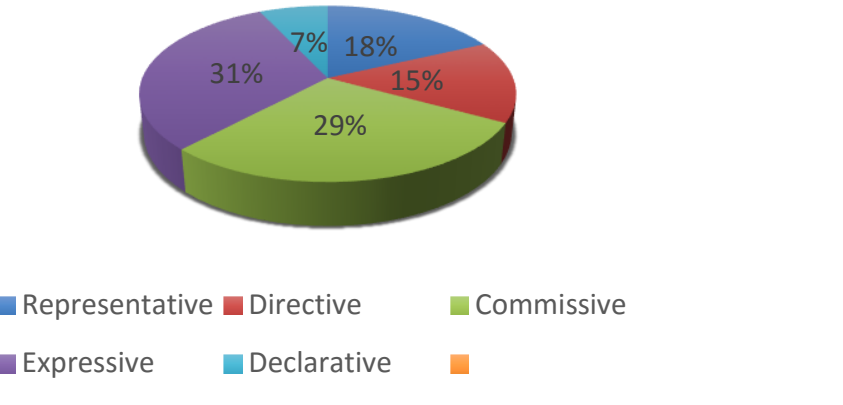

\section{CONCLUSION}

Based on the result of analysis, it can be concluded that the President Donald Trump used five kinds of speech acts. The five speech acts that is used are declarative, representatives, expressive, commissives, and directives. Declarative is used to declare something. Representatives is used to express clearly the truth by his utterances, or to inform something to listener. Expressive is used in his utterances to represent the psychological expression or emotion. Commissive is used to perform an action in the future. The last speech acts that is used by Donald Trump is directive used to get the addressee to do something.

Besides, the researcher also finds that the most dominant speech acts that is used by the President Donald Trump is expressive. There are 24 utterances from 76 utterances that belong to expressive. It is about $31 \%$ of the total percentage of the utterances. Finally, the researcher hopes that this research will give a contribution to the readers a better understanding of speech acts, and can be an additional reference for those who are interested in learning more about speech acts and also in making further study on similar topic.

\section{REFERENCES}

Byon, A. S. (2006). Apologizing in Korean: cross-cultural analysis in classroom settings. Korean Studies, 29(2), 137-166.

Dylgjeri, A. (2017). Analysis of Speech Acts in Political Speeches. European Journal of Social Sciences Studies, 2(2).

Jabber, Wahaab, K., \& Jinquan, Z. (2013). The Modal Verbs: A Speech Act of Request in the Speech of the President of the United States Barak Obama, (12), 2.

Kaswan, \& Suprijadi, D. (2011). Language in Society. Bandung: STKIP Siliwangi Press.

Lyons, J. (1977). Semantics. Cambridge: Cambridge University Press.

Searle, J. R. (1976). A Classification of Illocutionarry Acts., 5(1), 1-25.

Suprijadi, D., Lisdawati, I., Fauziah, U. N. EL, \& Supartini, N. (2016). Introduction to Linguistics. Bandung: STKIP Siliwangi Press.

Yule, G. (1996). Pragmatics. Oxford: Oxford University Press. 